\title{
The Interplays of Congruence and Social Identity Theories to Explain the Entrenched Market of Japan Made Car Products in Indonesia
}

\author{
Nasrul $^{1 *}$, Wahyuniati HAMID ${ }^{2}$ \\ ${ }^{1}$ Associate Professor, Dr, Faculty Economic and Business, Halu Oleo University Kendari, Indonesia. \\ Kampus Hijau Bumi Tridharma, Anduonohu, Kec. Kambu, Kendari City, Southeast \\ Sulawesi 93232, Email: nasruluho@gmail.com \\ ${ }^{2}$ Lecturer, Dr, Faculty Economic and Business, Halu Oleo University Kendari, Indonesia. \\ Kampus Hijau Bumi Tridharma, Anduonohu, Kec. Kambu, Kendari City, Southeast \\ Sulawesi 93232., Email: wahyuniati@uho.ac.id \\ ${ }^{*}$ Corresponding Author
}

\begin{abstract}
Received: 14.04.2021 Accepted: 19.08.2021 Published: 04.10.2021 DOI: 10.47750/QAS/22.184.08
\end{abstract}
\begin{abstract}
Japanese car producers have enjoyed the largest market in Indonesia. Though competitors from other countries also make a serious penetration, its dominance does not budge. Its car business dominance in Indonesia has attracted attention, and the study intends to identify factors that might play role in their business entrenchment. It focuses on resale value as a standard for wide acceptance's products, and looks into economic match, maintenance convenience, and perceived fitness as factors that determine its resale value. The choice to apply these constructs are guided by congruence theory Being overlooked by car business literature, the study attempts to explore the role of length of contribution factor that might moderate their effects on Japanese car resale value. This application is based on social exchange and social identity theories All of research' constructs are new, and becomes its' novelty. The findings could be that economic match, maintenance convenience, and perceived fairness have respectively significant effects on resale value, and that length of contribution significantly moderates the relationships of economic match, maintenance convenience, and perceived fitness to resale value. It reaches important conclusion that closeness to local market condition and demand, and contribution are important factors for a certain business, and resale value of Japanese cars is a good example.
\end{abstract}

Keywords: Resale Value, Economic Match, Perceived Maintenance Convenience, Perceived Fitness

\section{Introduction}

There have been many studies exploring factors that contribute to the preference of Japan made cars in Indonesia to others. The present study attempts to look into it with different angles, emphasing the role of social exchange and social identity theories. The application of self-image congruence in terms of collective selves could add the analysis richness. As a whole, it poses a new model with novel constructs. The presentation could add a new way to look to product dominance.

Besides, the study applies resale value as representing the dominance of Japan-made car products. Though many have discussed the dominance, there has been a little analysis concerning resale sale. It describes the persistence of Japanmade car products that even continue to their used cars Contrast to their competitors, their used cars has their market that prevents their price falling down significantly from their original prices. It means that people who cannot afford to purchase new Japan-made cars can look into used car market, and people are willing to purchase used cars. The large number of people who have inkling for used cars shows the widespread appreciation of Japan-made cars.
According to Gaikindo, dominance of Japanese cars has started since 1991. Among 10 car brands, 9 were from Japanese. They were Toyota, Suzuki, Honda, Mitsubishi, Nissan, Hino, Isuzu, Daihatsu, and Mazda, and one brand Mercedes-Benz from Europe. In 1996, another Europan brand BMW and American brand Opel came in. In 1997, more foreign brands in sight such as Ford, Hyundai, Volvo, Peugeot, Daewoo, Chrysler, Audi, S. Boxer (https://oto.detik.com/mobil/d-4050840/dominasi-mobil-merekjepang-di-indonesia)

However, composition did not hold as some should leave when they did not get profits as good as expected, and some enjoy more profits and market share. Toyota for example during 2017 sold 371.332 car units in Indonesia while Honda held second position selling 186.859 unit. While, Korean cars like Hyundai only sold 1.271 units or KIA sold 837 units. Japanese car producers held 98,21 percent of car market share in Indonesia in 2017. Other foreign producers fought over less than 2 percent of remaining market share. Specifically, they include German producer (0,5 percent), Chinese ( 0,5 percent), American ( 0,34 percent), South Korean $(0,2$ percent $)$ and Indian $(0,1$ percent $)$ (https://oto.detik.com/mobil/d-4050840/dominasi-mobil-merekjepang-di-indonesia) 
Observers ever mentioned entrenched market of Japanese car producers. It relates to emotional relationship that has long been built among Indonesian people. They have a strong preference that they can be called as Japanese car minded. It owes to condition dating back to 1970-an. At that time, Japanese cars succeeded in providing commercial cars has been able to meet Indonesian public need for transportation, something that European or American could not supply. It is supported by their capability to assembly car components in Indonesia that enables for cheaper price (https://www.100kpj.com/mobil/5758-mengapa-banyak-orangindonesia-suka-mobil-jepang)

Representing these facts the study looks to resale value construct that it observes only Japanese car products have so far enjoyed. The resale value provides circular effects back to consumers in terms of entrenchment of trust on Japanese cars. Consumers feel that buying Japanese car is almost risk-free as they can resell the car with reasonable price anytime they wan to. The study attempts to make model of Japanese car resale value being independent contract, and economic match, perceived maintenance convenience and perceived fitness being dependent constructs.

One important factor that determines Indonesian people's preference to Japanese car products is that their rather low prices. Observer argues that Japanese car producers commonly target people of low middle segment, and have made strategies that enable for cost-cuttings. This has made people develop convenient after sale product prospect in terms of cost affordability. In order to represent this nature, the study develop economic match construct. Particularly when Japanese manufacturers are getting more concerned with producing more fuel-efficient car. The word match refers to common people preference to cheap products that allows for cost affordability. Its dimensions should be car price affordability, maintenance cost affordability, fuel efficiency, and cheap spare-parts.

Another factor that relates to and supports economic match is perceived maintenance convenience. It refers to perception that car does not entail heavy maintenance after purchase. Its dimensions should consist of spare-part easiness, service shops availability and small treatment in service. Implicit within dimension of spare-part easiness is availability of genuine spare-part suitable to car specifications and a no time or effort needed to get the spare-parts (https://www.100kpj.com/mobil/5758-mengapa-banyak-orangindonesia-suka-mobil-jepang)

Beyond these factors, Japan-made cars generally have run through evolution, making much breakthrough in quality and state-to-the-art that make them in tune with public taste and needs overtime. Their evolution attracts public interest and bring into being long-term attachment. The study develops construct perceived fitness to represent public acceptance due to Japanese car evolution. Its dimensions consist of quality fitness and local need fitness. Quality fitness for example covers items of durability, handling, modern technology, and material and body design development, while adaptation ability allows fitting to current issues. Local need fitness allows for accommodation current issues such as environment, compactness related to narrower roads, safety and others, demand changes, and demands from various social segments.

The study novelties lay on its new constructs, with new model as a consequence. The intention is to make a model that describes factors that leads to resale value of Japan made cars. To complete the description, the study also applies length of contribution though as having moderating effects on the relationship between those factors and resale value. Put in another words, the study intends to find out the effects of economic match, perceived maintenance convenience, and perceived fitness on resale value with length of contribution as moderator. It also means that the study is among few which put forward a model that involves social exchange, social identity, and congruence theories. Social exchange theory provide a base to grasp the fact that Japanese manufacturers have long given a significant contribution to transportation provision in Indonesia history and whether this has effect on their preference over Japan made cars. Social identity theory is useful to comprehend Indonesian consumer's tendency to develop brand identification in the form of this preference.

\section{Theoretical Review}

\subsection{Social Exchange}

Social exchange theory holds that most relationships between individuals are based on calculation of rewards, costs, and profits. There should be balance between them, without which the relationships would be at risk. Individuals could decide to leave a relationship when they see the costs to burden outweigh the expected profits.

The theory was developed by John Thibaut and Harlod Kelley, (2017), George Homans (1961), Richard Emerson (1962), and Peter Blau (1964). They see society as being formed by relationships with take-and-give patterns. Individuals usually maintain relationships that provide more profits than its costs. It could explain individual behaviors in maintaining or leaving relationships with commercial organizations.

The theory could be relevant when Indonesian people still consider that Japanese car manufacturers has had a great contribution in the fulfillment of public transportation need. They were the only car producers that have been able to tailor their car products to people's social and economic conditions time after time since 1960's. Refinement has been around gradual following the development of people economic and taste. Flexibility and willingness to tune with consumer dynamic of demands have become the the advantages that they enjoy and others could not emulate. These advantages have created a strong chemistry between Japanese cars and Indonesian consumers. This bond is formed out of great appreciation and mutual recognition of each party, resulting in adequate products with acceptable prices and sense of belonging. This might make consumers hard to turn away their embrace on Japanese products even in the face of increased appeal from competitors.

\subsection{Identification and In-group-Bias}

Identification is individuals' decisions to make closer relationship to a certain brand, organization or product driven by sommon commonness, attractiveness, reputation, or prestige. At this point, the brand, organization or product in question is perceived to be important social group of which an individual is motivated to be part. Individuals could look to external objects to reflect their identity, image, fondness and support through their relationship. They step out from themselves to reach other object they think could strengthen this identity, image, fondness and support widely enough that other people could see and appreciate it altogether. This relationship could take place to organization, brand, or product which is respectively called organization identification, brand identification or product identification.

This identification strengthens both identities of individuals and of objects they identify (Anderson and Chen, 2002). The final result could be heightened commitment to foster relationship (Ashforth and Mael, 1989). The commitment could take the forms of repurchase frequency of the same brands, strong intention to revisit, and preference. 
In the forming process of relationship, individuals develop positive feelings about themselves and organization on which they make affiliation. All these positive feelings and ideas could result in categorization. While those people associate themselves with positive things, it could mean that they attach negative things to other people outside. In social identity theory, it is called categorization. Affiliation which is based on positive evaluation, judgment and consideration endows ingroup people with positive way of life, while others categorized as out-group are otherwise.

Categorization and in-group favoritisme is intertwined concepts. It means that one leads to another. It comes from the need to provide legitimacy to the action of affiliation as a good or right thing to do. Consent from the most members serves as a confirmation that maintains group cohesion and sustainability. There are some rules of thumb that each member should follow. Each different action might be read as deviation and tendency to leave the group. Sanctions are commonly social, such as the loss of support, the absence of recognition, disapproval and the likes.

\subsection{Self-Congruence Theory}

The present study puts forward economic match, perceived maintenance convenience and perceived fitness which al emphasis meeting points with consumers' conditions, buying power, taste, attitude, and needs. So far the only theory that supports this nature is self-congruence theory. This theory argues that Individual tends to purchase products that have resemblance to his or her ideas or ideal of self (Sirgy, 1982). The purchases strengthen these ideas or ideals. It means that products chosen to buy convey symbolic meaning to individual buyer (Birdwel, 1968). He or she could create, strengthen, maintain, express, associate, and differentiate of the self by means of certain product consumption (Ahuvia, 2005; Dittmar, 2007). Decision to consumption could relate to explains individual's personal history, aspiration, reflection of interpersonal social relation, cultural values, social status (for example, Belk (1988)).

The constructs of economic match, perceived maintenance and perceived fairness more refer to collective selves as society rather than individual self. Aspiration of enjoying car vehicle with a significant affordability represents the need of majority. Managerial strategy to focus service coverage on middle-to-low income population is in line with the characteristic of developing countries, which Indonesia is the one. The low price has enabled many Indonesian people own car, engendering the thought that Japanese manufacturers could materialize cars as primary need, instead of tertiary need any longer. It is because its affordability represented by economic match, low service cost due to common small service treatment represented by perceived maintenance convenience, and their durability represented by perceived fitness.

Thus, the study is among few that applies congruence perspective in terms of collective selves. It has potential to enrich management literature regarding congruence in terms of collective selves, and contribute to self-image congruence perspective to accommodate collective selves in the analysis.

\subsection{Subjective Norms}

Subjective norms together with personal attitude and perceived behavior control affect behavioral intention. Subjective norms represent the perspective that refers to the perspective that another people or group of people approve or disapprove a particular behavior. Subjective norms serve as social pressure from others to perform a certain behavior and follow what they think better or best.

The idea was initially proposed by Ajzen (1991). The pressure of growing number of significant others could be indicated as social pressure from environment. The rise could indicated by and be seen by individuals as growing agreement and confirmation of a certain choice.

Previous works show the strong relationship between social norms and behavioral intention such as Kamble et al (Kamble et al, 2020) and others. While many others have proved that subjective norms have weak relationship on behavioral intention (Ham et al, 2020). The results of the present study would reveal unique phenomenon of subjective norms' strength in providing influence. It puts forwards constructs in its research model that contains subjective norms' nuances.

\subsection{Hypothesis Building}

\section{Economic match and resale value.}

Economic match refers to cheaper prices compared to counterparts' car prices, costs in maintenance cost affordability ranging to cheap services to cheap spare parts, and fue efficiency resulting in cheaper oil consumption. Japanese cars have these characteristics. Japanese cars exceed in these terms, especially when compared to European cars. European manufacturers commonly make luxurious cars, made from high-quality steel, with higher prices as consequences. Their spare parts are rare and high price, plus integrated electronic system, leading to costly service (https://otomotif.kompas.com/read/2020/08/08/110100215/inialasan-kenapa-mobil-bekas-pabrikan-jepang-lebih-larisketimbang-eropa?page=all). Korean cars are assumed to offer competitive price, better quality, but with rarer spare parts and service shops (https://garasi.id/artikel/bingung-mau-beli-mobiljepang-atau-korea-5-perbedaan-ini-bisa-

jadi/5ca1908d51f72f0261165f87). Chinese cars have cheaper prices; more advanced system, but with the same rarer spare parts and service shops.

This economic match makes Japan-made cars stand out over competitors, and come first in consumers mind in picking cars. Consumers put persistent value even to used cars as economic match consideration still holds to new and used cars. Consumers put persistent value even to used cars as economic match consideration still holds to new and used cars. The work of Erdogmus and Budeyri-Turan (2012) about the role of personality congruence showed that personality congruence affects perceived quality and brand loyalty. They found that meeting points of personality brand traits which in their case consist of sincerity, competence, and excitement and consumer personality preferences play an important role. The work of Ekinci et al. (2013) about self-congruence and lifestylecongruence and their relationships on destination brand loyalty Thus, we put forward the following hypothesis:

$\mathrm{H} 1$. Economic match has a significant effect on resale value

Perceived maintenance convenience and resale value.

Perceived maintenance convenience refers to easiness in terms of service shop and spare-part availability, lightness in vehicle maintenance meaning that a trouble in one component does not cause spreading effect to other components that might cause higher cost for repair, and after-sale services that make Japan-made car owner enjoy free service after certain periods of car purchase. Most of these comforts are hard to find in European case. For Korean and Chinese counterparts, still Japanese manufacturers are still dominant in service shop and spare-part, as well as after sale service provisions.

Long operation in Indonesia and high sales has driven some Japanese manufacturers to improve service shops in terms of coverage and quality. They have realized the importance of satisfaction from after sale service. Balance between before and after sale services encourages consumers 'positive attitudes. Even some have at empted to emulate service quality in Japan, both before and after sale 
(https://www.otosia.com/berita/suzuki-niat-samai-standarbengkel-jepang.html). This allows for unmatched that strengthens resale value of Japan-made cars. Chang et al (2010) and Chen et al. (2019), among others, have emphasized the importance of perceived convenience on loyalty. Based on these as background, it hypothesizes that:

H2. Perceived maintenance has a significant effect on resale value.

Perceived fitness and resale value.

Perceived fitness grasps ability of Japanese manufacturers to maintain their products in line with public demand and conditions. By this way, their products always achieve acceptability. They take into account of technological advance, feature significance, development of materials used and body designs, and adaptation ability that allows them to to fit to current issues, demand changes, various segments' demands and to local roads. Japan-made cars have run through technological development that leads to wide acceptance because of being thought of having increasing quality. It is accompanied by increasing development of features that heightens driving comfort and safety. Japan-made cars also have been designed to suitable to local roads which are often uneven and plagued with holes. Even though Europe-made cars have more excellent technological advance, feature significance and body design, but they are not tailored to condition of Indonesian roads. Japan-made cars have more various types to correspond to various demands and demand change. People have witnessed Japanese car manufacturers' commitment in and the facts of continuous improvements in their car product technology and quality. It instills them strong trust in their reliability as right company for work, business and family.

This witness of Japanese car manufacturers' capability to make a significant improvement ushers to value persistence ranging to use cars. These values could carry a desired and actual image. The work of Malar et al (2013) showed that brand could achieve the level of emotional brand attachment when the brand carries perceived actual self-congruence and perceived ideal self congruence. The work of Sung and Huddleston (2017) showed the same case. They argued that need for social-image congruence could lead to brand preference. Their study results confirm that consumers with high need for self-image congruence prefer well-known products to emphasize their preferred image. Thus, it hypothesizes that:

$\mathrm{H} 3$.

Perceived fairness has a significant effect on resale value.

Length of contribution Moderates Relationship Between Economic Match and Resale Value.

Japanese manufacturers have longest history in vehicle provision in Indonesia compared to its counterparts. Its long experiences with Indonesia nature of economy and consumer preference equip them with valuable knowledge on what to do to next business policy and products. Long familiarity with Japanese cars strengthens a base of solid relationship with consumer. Their long reliability assures positive response to any measures intended to strengthen the relationship.

Japanese car manufacturer recognition that Indonesian population contour is mostly composed of low middle income people. Their strategies are guided by low-cost principles ranging from low-cost production, affordable spare-parts and services balanced with car toughness that can handle rough roads and prevent owners from often-service and care to fue efficiency that determine Japanese resale value. Consumers' familiarity with the products tend to emanate faster positive attitude as Japanese manufacturer successfully design products more efficiently overtime with resulting higher value. As long relationship allows them to harbor sense of oneness to the products, this could strengthen the effect of any development that accentuates affordability nature or purchaseworthiness in terms of continuously refined product-cost comparison. The same case might not hold true to other country products. Under social exchange and in-group bias theories, people do not behave equally to different products even in the same category. Long contribution incurs both desire to respect and repay the benefits, and strengthens relationship when they witness transformation that brings reputation to Japanese car products. When people include a certain product into themselves, they would treat the products differently from others. By this way, competitors should have different strategy to obtain the same results. In other words, competitors measures to follow what Japanese manufacturers have done might incite different response from Indonesian consumers. Thus, long relationship could strengthen the effect of economic match and resale value. It accordingly makes hypothesis that:

$\mathrm{H} 4$. Length of contribution significantly moderates the effect of economic match on resale effect.

Length of contribution moderates the effect of perceived maintenance convenience on resale value.

Japanese car manufacturers have long made a huge effort in creating after sale-convenience to consumers. They condition situation where widespread service centers are easy to find for consumer seeking car service. High technology tools, well-trained personnel, and spare-part completeness assure the trust for service quality with affordable cost. The availability of original spare parts also signals the sustainability and worthiness of Japan-made cars. They have succeeded to convince the consumers that only Japan-made cars provide benefits without losing risk in the present time and future.

Long acquaintance that makes people see the transformation of Japan-made cars in reliability and toughness terms with little financial risk in the future allows people to develop emotional relationship and positive attitude much faster compared to competitors. This recognition leads to appreciation which competitors cannot offer. Thus, it hypothesizes that:

H5. Length of contribution significantly moderates the effect of perceived maintenance convenience on resale value.

Length of Contribution Moderates Relationship Between Perceived Fitness and resale value.

Perceived fitness has not only made Japan-made cars comparable to its European or American counterparts and acceptable to world-wide consumers, but also has allowed them to achieve market dominance. State-to-the-art technology, feature significance, material and body design development, and adaptation ability have instilled them persistent values. Japan-made used cars still maintain high values and can be offered with fairer prices compared to their competitors. Materials and designs develop overtime, not to mention features that are always in tune to development of consumers' demands. Complete variants to cover diverse consumer segments imbue consumers with multiple choices that determine their preferences.

Japanese car manufacturers' long history of operation in Indonesia deserves appreciation. Their willingness and obvious commitment to fulfill public need of transportation. Could strengthen the persistence of Japan-made cars' resale value affected by perceived fairness. This strongly molds pervasive idea that Japan-made cars go through sophistication in time, have growing durability, green accommodation, thus worthiness to posses, including even used cars, and in terms especially their affordability. The study accordingly conceives that the appreciation play role in strengthening the effect of perceived fitness to resale value. It hypotheses that:

H6. Length of contribution significantly moderates the effect 
of perceived fitness on resale value.

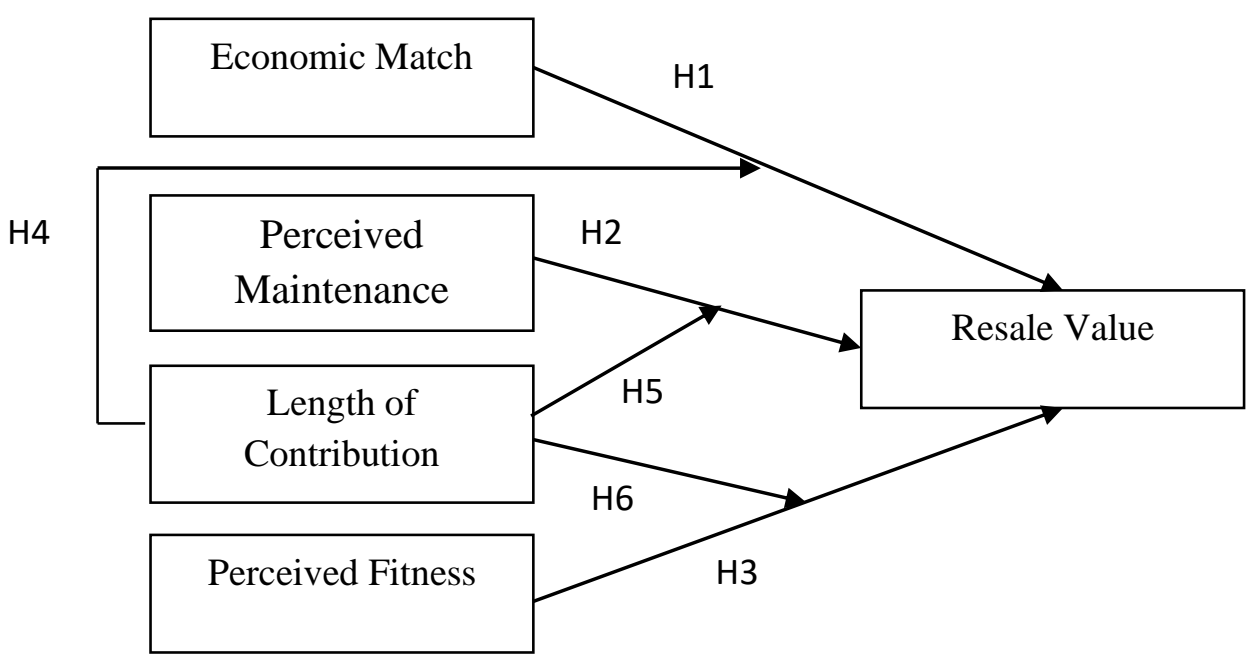

Figure 1. Conceptual Research

\section{Methodology}

It starts with library review to identify specific-country constructs and their related dimensions. It applies convenient sampling as sampling technique. Regarding to sample size, it follows Malhotra (1993), who sets out that sample size could be determined by means of formula of multiplication of indicator number to 5 to 10 times.

Before contributing questionnaires to respondents, researchers will carry out content validity, face validity, construct validity and pre-test to around 30 respondents. Content validity involves expert judgment, while face validity involves judgment some segment of respondents (GrothMarnat, 2009). Regarding to construct validity, the study applies factor analysis, by looking into $\mathrm{KMO}$ value which should be over 0, 6 as standard for validity (Cronbach, 1951).

Respondent should be Japan-made car consumers indicated by proofs of ever owning more than one Japan-made car in the present or past time. They are contacted online and offline. Online respondents should send relevant photos or videos to make sure that the respondents have preference to Japan-made cars. They can have the cars in different times. Questionnaire distribution would be in big cities in Java covering Jakarta, Surabaya and Bandung. They are endowed with biggest population in Indonesia and largest millennial that are important in order to grasp the recent and majority perspective.

\section{Results And Discussion}

Economic match should have a significant effect on resale value. So far Japan-made car products have the most leverage for low cost burden which is a common demand of developing country society. Their long operation Indonesia has endowed them time and opportunity to build supporting facilities and procure spare parts that ascertain low cost services and spareparts. Some competitors have attempted to follow the same patterns, only to find that this position is still occupied by Japanese car manufacturers. The highest congruence that Japanese car manufacturers have achieved have allowed for strongest relationship between them and public in mind and heart. This explains the persistent values of Japan-made used car products. Consumers who do not afford to buy new car are usually willing to look forward to use car to come with lower price but still reliable products.

Relationship between economic match and resale value is strengthened by Japanese car manufacturers' length of contribution in Indonesia. This length of contribution provides people opportunity to witness this congruence, assuring that the products serve as best choices. It could save them from information-gathering activity to find out which one offers the most benefits by comparing to competitors' products. Length of contribution also serves as a base for consumers to make positive judgment as they have been seeing that Japan-made car products have made great participation and continuous commitment since a much earlier time for transpiration service provision.

Perceived fitness should have a significant effect on resale value. Though European, US or other made cars have a more superior technology, better outlook, or higher quality in materials, perceived fitness reflects people appreciation to the point of acceptability of their weaknesses or downward points as these being offsite by opportunity to own car due to their reasonableness in terms of price to worthiness comparison. It more pertains to provision of chance in possessing quality car products previously considered unlikely due to high price. This perceived fitness engenders this liking, which goes on to use cars. It explains that Japan-made used cars have persistent value and their own market.

Relationship between perceived fitness and resale value is strengthened by Japanese car manufacturers' length of contribution in Indonesia. The long operation in Indonesia and significant contribution to fulfillment of transportation need magnify sense of attachment molded by perceived fitness in the form of value persistence. Close relationship between consumers and car product due to fitness is buffered by their witness and appreciation of Japanese car manufacturers in developing car quality, which in turn further strengthen their value.

Perceived maintenance convenience should have a significant effect on resale value. Consumers of Japan-made car products usually enjoy service convenience before and after sale, and have care-freedom after purchasing. It is due to dominance in service performance in terms of service shop and spare-part availability. Japanese manufacturers have managed to procure service shops around public places, and even some of them have attempted to upgrade their service quality to 
international standards. To most of Indonesian people, purchasing decision, especially to products of secondary need category, should result on immediate benefits, minimum risks, and absence of additional burden. People could draw on Japan-made car products without worry of heavy maintenance incurring high costs, equipped with easily-reached service shops and readily-available spare-parts. This luxury helps buffer their values that go on even to used products.

Long operation in Indonesia and significant contribution to transportation service provision arises assurance that Japanese manufacturers have shown steady commitment in transportation service, that only have they proven ability in the provision that in line with Indonesian majority condition. It arises desire of closer relationship and sense of belonging, empowered by emotional attachment.

This attachment becomes hindrance to competitors that attempt to emulate or even overtake the measures the Japanese car manufacturers. Relationship molded by emotional feeling is hard to follow, and becomes the leverage that can be capitalized on for competitive edge. This emotion arisen from long and intensive contact amplifies the effect of perceived maintenance convenience on resale value, as emotion is the strongest energy that tends to last. It works in a contradictory way to logic. The offer of better products with lower prices by competitors is not sufficient to change the attitude.

Nowadays, people view economic match, perceived maintenance convenience, and perceived fitness as integral part that become the leverage of Japanese on vengeance made cars. Their combination forms a solid congruence in terms of public needs, taste, aspiration and identity expansion. At much earlier time, economic match might have come first in consumers' minds. It was because early products offered with low price but accompanied with low quality in materials and design. Then service shops and spare part availability are not as easy as we can find today

At the same earlier time, Japanese manufacturers cater to national-wide collective selves. Overtime, they learned, and still do, to follow collective selves according to different segments. This is especially so, as Indonesian people gets more prosper, and their purchasing power increase, still with different needs and purposes. Or even tastes. The consistence in developing services and continuous refinement, guided with congruence to collective selves, strengthen their persistent values.

Right now, these constructs are not mutually exclusive. Instead, they are mutually supportive and have become intertwined. It poses a great challenge to competitors who have attempted to crack open Indonesia's car market. Chinese car manufacturer is one of them with high quality and low products. The lack of perceived maintenance convenience could be a huge hindrance. Korean made cars could suffer the same plague. The conspicuous gap is obvious on European made cars which might suffer the lack of economic match, perceived maintenance convenience and perceived fitness.

Actually, the competitors in a certain extent have congruence degree on their own. They have their own certain congruence. It explains that they have their own fans. However, the degrees still do not reach what Japan made car products have reached. So far, the closer degrees of congruence to that of Japan-made cars have been achieved by Chinese and Korean made car products. Another important thing to note is that the closer competitors will be in congruence degree of Japan-made car products have been, the more the latter will make further improvement that widen ever more the gap between them.

Manufacturers could choose to maintain self-image congruence strategy, instead of collective selves congruence strategy, or otherwise. Both work in different ways, but could equally lead to brand equity. Though European-made car products do not dominate market share, they do have a loyal market with a clear segment. The consumers have a common characteristic of staunch loyalty, with motivations of social status and identity enhancement. The less congruent the products are, the more appealing they are to the consumers. The departure from most consumers puts them in a highly specialized social class.

Social identity theory might explain the two cases. In European case, categorization perspective which is part of social identity theory holds that people are attracted to brands or products that allow them to separate from others. By this way, their presence is easily recognized, and their social class is easily identified. They do not bother to develop positive image for in-group members that is those who afford to purchase. Privilege is automatically attached. In Japanese case, subjective norms which in social identity theory are postulated as one factor that affects individual intention to purchase might explain the phenomenon. Subjective norms refer to people considered important in directing their behaviors. The bigger they are the more stringent stress they impose to individuals to conform. Since the number of individuals who own and positively judge Japan-made car products is large, the more stress people will feel to do the same. This large number is indirectly indicating large-scale approval of Japan-made car products and their purchases would be accompanied with social approval as a consequence. At this point, we arrive at the idea that small and large numbers of members, that is those who purchase the products only from a certain country, both have appeal. Conformity and escapism are drivers that infidel apply to judge and select products or brands.

Some studies have shown that brand consumption carries social value, with intention to obtain social approval (Muniz and O'Guinn, 2001; McAlexander, et al., 2002). They use brand to signal membership in group of like-minded consumers. Individuals always have the need to live in group as a way to be more clearly seen by others. They also have the need to belong ( Miniard and Cohen, 1983 ; Csikszentmihalyi, 2000 ).

However, brand consumption could also signify desire to break away from a bulk of other people, reflecting need recognition of specialized position in society (Labrecque et al, 2011). Some works develop concepts raised from this diverging desire such as consumer innovativeness and escapism motivation. Consumer innovativeness refers to individual readiness to break from common behavior in purchasing decision-making due to new technology, higher quality, and more benefits that individuals consider more important than existing counterparts. Some consumers do have a significant interest to a new technology and idea irrespective what other people think or do (Midgely \& Dowlin, 1978). Regarding to escapism motivation, literature has more exploration in tourism and brand management. It refers to motivation to break from common habit because of boredom, dissatisfaction or novelty-seeking.

In-group bias concept which is a part of social identity theory argues that individual members tend to solidify member cohesion by developing positive image for them and negative image for others commonly called out-group. Members attempt to follow organization norms dictating which is appropriate and which is not. Buying the same products or those under the same category with those bought by member majority sends a signal of conformity. It also could mean a need to have a positive judgment from other members that lead to perceived contribution to group image. Their growing number could be read as a signal that all members work, as they should, to heighten group image by practicing the same norms, in this case purchasing the same car products. Doing otherwise could 
mean disagreement to a group norm. It could amount to evaluation that he or she is no longer member or a part of group, as he or she does not reflect group norms.

Group is not necessarily physical. Consumers often develop social identity around a brand or product as a menta origination on which the social identity is based. Group identification does not have to be necessarily formal. Sanctions or rewards to members are rather loose, but obvious in the forms of attitude and behavior. Product or brands can act as symbols with social meaning Mick (1986). People need respect and social acceptance. Purchasing a certain product in order to fulfill this need is a social behavior. The purchasing helps people to come into a particular social group (Slater, 1997). By doing this, they emphasis their social identity (Bhattacharya \& Sen, 2003). The process is called identification, and the identity they rely on can be informal, imagery or inspirational Kuenzel and Halliday, 2008).

\subsection{Limitations and Future Research}

The study does make any specific categories of car for comparison to be analyzed. Categories like MPV, SUV, sedan or others might have different reasons. Future research could continue the analysis with these specific categories. The study also does not include demographic factors that might play a part. It applies novel constructs in its research model. The dimensions of each construct still needs refinement and justification from management experts and field managers. The venerability of the study results could be at issue, as the study follows perspective of Indonesian consumers. However, low price and proven durability, with continuous development in quality, have universal appeals.

Future research might consider to deepen the analysis by exploring the effect of perceived maintenance convenience on economic match as the former contains convenient cost that might strengthen economic match, or the effect of perceived fitness on perceived maintenance convenience as perceived fitness contains durability that has relation to common small service treatment requirement contained in perceived maintenance convenience Other construct with equally powerful effect possibility might also worth exploring. One good example is $\mathrm{COO}$ (country of origin). The exploration could widen knowledge whether $\mathrm{COO}$ or even $\mathrm{COO}$ image has a role in car purchasing decision-making. This is especially so as Japanese brands have set foot on a solid ground in the mind of most Indonesian people.

Comparison to another country would provide a more complete picture as to competition among car manufacturers, and whether a different model is in command. It pertains to fact that only has Japanese car manufacturers had a long and deep contribution since the history of car industry started in Indonesia.

Research on conditions that might trigger purchasing decision to follow or deviate from common norms could further enrich knowledge. The conditions could range from types of products, of innovation, of benefit to special events.

\section{Conclusion}

Management literature could start to turn to congruence in terms of collective selves. This issue is so far still underexplored. Some papers may neither mention it in detailed way, nor support it with research. The present study might serve as filling the gap, as showing the importance of collective selves play the role. From this, managers could learn whether to give appropriate address as to product designs that carry conformity to collective selves or those with specialized personality those carter individual selves that demand distinctive features. Both beset emotional involvement that foster relationship.

The study shows relationship between congruence of collective selves and subjective norms in planned behavior theory. The difference is that subjective norms refer to the influence of some important others in shaping attitude and behavior. They are certain people with important role or position whose opinions other people should take into account of. They are exclusive people and limited in number. Selfimage congruence emphasizes image at individual level in narrower sense. Identification in social identity theory sheds light on belonging motivation to social identity that both nuances exclusivity and universal values such as success, vigilance, quality or others that attract a large number of people. In this case, congruence in collective selves' terms are more related. For the case of Japan-made car dominance in Indonesia, congruence in collective selves' terms and social identity theory are appropriate accordingly.

The inclusion of collective selves in congruence theory worth's deeper exploration, as theoretical literature so far only recognizes self image congruence at individual level. It could drive attention to enrich this literature by widening the emphasis to not merely on image, but also on need, desire, motivation, aspiration or other. The present study puts forward economic match to picture congruence to people affordability, perceived maintenance convenience to refer congruence to people demand the purchase as solution to transportation without bothering other financial burden or risks., and perceived fitness to shed light on product suitability to current issues such as security, green awareness, and others, current technological, material, design development or even local roads. It is also important to widen the analysis scope from individual level to public level.

The present study also shows that there is interplay between congruence and social identity theories to explain Japan-made car products in Indonesia. It goes further by showing that this interplay is strengthened by appreciation and recognition represented by length of contribution and explained by social exchange. This length of contribution is that other competitors do not have. Quantitative research could measure the extent that this construct affect others.

\section{References}

[1] Ahuvia, A. C. (2005). Beyond the Extended Self: Loved Objects and Consumers' Identity Narratives. Journal of Consumer Research, 32(1), 171-184. doi:10.1086/429607

[2] Aizen, I. (1991). The theory of planned behavior. Organizational Behavior and Human Decision Processes, 50(2), 179-211. doi:10.1016/0749-5978(91)90020-t

[3] Bhattacharya, C. B., \& Sen, S. (2003). Consumer-Company Identification: A Framework for Understanding Consumers' Relationships with Companies. Journal of Marketing, 67(2), 7688. doi:10.1509/jmkg.67.2.76.18609

[4] Birdwell, A. E. (1968). A Study of the Influence of Image Congruence on Consumer Choice. The Journal of Business, 41(1), 76. doi:10.1086/295047

[5] Blau, P. M. (1964). Justice in Social Exchange. Sociological Inquiry, 34(2), 193-206. doi:10.1111/j.1475682x.1964.tb00583.x

[6] Csikszentmihalyi, M. (2000). The Costs and Benefits of Consuming. Journal of Consumer Research, 27(2), 267-272. doi:10.1086/314324

[7] Chang, K., Chen, M., Hsu, C., \& Kuo, N. (2010). The effect of service convenience on post-purchasing behaviours. Industrial Management \& Data Systems, 110(9), 1420-1443. doi:10.1108/02635571011087464

[8] Chen, K.-H., Chang, F.-H., Chen, Y.-L., \& Chen, P.-M. (2019) 


\section{GENERAL MANAGEMENT}

The Relationships between Corporate Credibility, Service Convenience, and Consumers' Use Intentions: Toward Ticketing Apps for Low-Cost Carriers. Sustainability, 11(3), 810. doi:10.3390/su11030810.

[9] Dittmar, H. (2007). Consumer culture, identity and well-being: The search for the "good life" and the "body perfect." Consumer Culture, Identity and Well-Being: The Search for the "Good Life" and the "Body Perfect" (pp. 1-271). Taylor and Francis. https://doi.org/10.4324/9780203496305

[10] Ekinci, Y., Sirakaya-Turk, E., \& Preciado, S. (2013). Symbolic consumption of tourism destination brands. Journal of Business Research, 66(6), 711-718. doi:10.1016/j.jbusres.2011.09.008

[11] Erdoğmuş, İ., \& Büdeyri-Turan, I. (2012). The role of personality congruence, perceived quality and prestige on ready-to-wear brand loyalty. Journal of Fashion Marketing and Management: An International Journal, 16(4), 399-417. doi:10.1108/13612021211265818

[12] Emerson, R. M. (1962). Power-Dependence Relations American Sociological Review, 27(1), 31. doi:10.2307/2089716

[13] Ericksen, M. K. (1997). Using Self-congruity and Ideal Congruity to Predict Purchase Intention. Journal of Euromarketing, 6(1), 41-56. doi:10.1300/j037v06n01_04

[14] Ham, M., Jeger, M., \& Frajman Ivković, A. (2015). The role of subjective norms in forming the intention to purchase green food. Economic Research-Ekonomska Istraživanja, 28(1), 738748. doi:10.1080/1331677x.2015.1083875

[15] Higgins, A. C. (1961). SOCIAL BEHAVIOR: ITS ELEMENTARY FORMS. By George Caspar Homans. New York: Harcourt, Brace and World, Inc., 1961. 404 pp. \$5.50. Social Forces, 40(2), 180-181. doi:10.2307/2574301

[16] Kamble, Z., Doan, Q. T., Nguyen, H. N., Zeng, Z., \& Liao Zihui, L. (2020). The Significance of Online Reviews for Hotel Entrepreneurial Success. Entrepreneurial Development and Innovation in Family Businesses and SMEs, 75-86. doi:10.4018/978-1-7998-3648-3.ch005

[17] Khan, M. S., \& Dash, S. (2014). A Study of Impact of Motivation on Productivity of Employee. The International Journal Of Business \& Management, 3(8), 2321-8916. Retrieved from www.theijbm.com

[18] Kuenzel, S., \& Vaux Halliday, S. (2008). Investigating antecedents and consequences of brand identification. Journal of Product \& Brand Management, 17(5), 293-304. doi:10.1108/10610420810896059

[19] Labrecque, L. I., Krishen, A. S., \& Grzeskowiak, S. (2011) Exploring social motivations for brand loyalty: Conformity versus escapism. Journal of Brand Management, 18(7), 457-472. doi:10.1057/bm.2011.12

[20] Levy, S. J. (1981). Intepreting Consumer Mythology: A Structural Approach to Consumer Behavior. Journal of Marketing, 45(3), 49-61. doi:10.1177/002224298104500304

[21] Malär, L., Krohmer, H., Hoyer, W. D., \& Nyffenegger, B. (2011). Emotional Brand Attachment and Brand Personality: The Relative Importance of the Actual and the Ideal Self. Journal of Marketing, 75(4), 35-52. doi:10.1509/jmkg.75.4.35

[22] McAlexander, J. H., Schouten, J. W., \& Koenig, H. F. (2002). Building Brand Community. Journal of Marketing, 66(1), 38-54. doi:10.1509/jmkg.66.1.38.18451

[23] Mick, D. G. (1986). Consumer Research and Semiotics: Exploring the Morphology of Signs, Symbols, and Significance. Journal of Consumer Research, 13(2), 196. doi:10.1086/209060

[24] Midgley, D. F., \& Dowling, G. R. (1978). Innovativeness: The Concept and Its Measurement. Journal of Consumer Research, 4(4), 229. doi:10.1086/208701

[25] Miniard, P. W., \& Cohen, J. B. (1983). Modeling Personal and Normative Influences on Behavior. Journal of Consumer Research, 10(2), 169. doi:10.1086/208957

[26] Muniz, A. M., \& O'Guinn, T. C. (2001). Brand Community. Journal of Consumer Research, 27(4), 412-432. doi:10.1086/319618

[27] Natsuda, K., Otsuka, K., \& Thoburn, J. (2015). Dawn of Industrialisation? The Indonesian Automotive Industry. Bulletin of Indonesian Economic Studies, 51(1), 47-68. doi:10.1080/00074918.2015.1016567

[28] Sirgy, M. J. (1982). Self-Concept in Consumer Behavior: A Critical Review. Journal of Consumer Research, 9(3), 287. doi:10.1086/208924

[29] Thibaut, J. W., \& Kelley, H. H. (2017). The Social Psychology of Groups. 1-3342, doi:10.4324/9781315135007 